\title{
Bird conservation on electric-power lines in Hungary: Nest boxes for saker falcon and avian protection against electrocutions. Projects' report
}

\author{
Ochrana vtáctva na elektrickom vedení v Mad'arsku: Hniezdne búdky pre sokola rároha \\ a ochrana vtákov pred usmrtením elektrickým prúdom. Projektová správa
}

\author{
József FIDLÓCZKY, János BAGYURA, Károly NAGY, Péter TÓTH, \\ Tamás SZITTA \& László HARASZTHY
}

\begin{abstract}
Bird conservation on electricity transmission lines has a 40-year history in Hungary. It started with the saker conservation program. The initial small-scale activities were considerably enlarged through the LIFE projects. In the first project, 301 nest boxes for sakers of a new type made of aluminium were installed on pylons of high-voltage transmission lines. In 2013 nearly $70 \%$ of saker pairs nested in these new boxes. An estimated 100000 different birds used to be killed annually on the transmission line pylons in Hungary. During the two LIFE projects about 14300 pylons were made bird-safe using improved technology and materials. Nearly 800 new bird-safe crossarms of pylons are being installed in the second project, which is expected to completely eradicate the danger.
\end{abstract}

\begin{abstract}
Abstrakt: Ochrana vtáctva na elektrickom vedení má v Mad'arsku 40-ročnú tradíciu. Začala s programom na ochranu sokola rároha. Počiatočné maloplošné aktivity sa značne rozšírili v rámci projektov LIFE. Počas prvého projektu bolo na stĺpy vysokého napätia umiestnených 301 hliníkových hniezdnych búdok nového typu pre rároha. V roku 2013 hniezdilo v týchto búdkach takmer 70 \% párov sokola rároha. Odhaduje sa, že ročne zahynulo na stĺpoch elektrického vedenia v Mad'arsku 100000 jedincov vtákov. V rámci dvoch projektov LIFE bolo 14300 stĺpov ošetrených tak, že sa stali bezpečnými pre vtáctvo. Počas druhého projektu sa na stĺpy nainštaluje takmer 800 nových, pre vtáky bezpečných konzol, vd'aka čomu očakávame kompletné odstránenie rizika úrazov vtáctva spôsobených elektrickým prúdom.
\end{abstract}

Key words: bird roost, crossarm design, transmission line pylon, wing spacer

József Fidlóczky, FENCON Ltd., Erkel u. 6/a, 2092 Budakeszi, Hungary. E-mail: jozsef.fidloczky@fencon.hu (corresponding author).

János Bagyura, Károly Nagy, Tamás Szitta, László Haraszthy, MME/BirdLife Hungary, Költő u. 21, 1021 Budapest, Hungary. E-mail: bagyurajanos@invitel.hu,nagy.karoly.mme@gmail.com, tamas.szitta@gmail.com, haraszthyI@gmail.com.

Péter Tóth, Agria Ökoszisztéma Kft. Rózsa Károly u. 12/b. 2/5, 3300 Eger, Hungary. E-mail: toth.peter.eger@freemail.com.

Acknowledgements: The authors would like to thank everyone who has contributed to the protection of birds on the electricpower lines, especially for the good co-operation and work of the electricity companies (MAVIR Zrt., ÉMÁSZ, EDF-DÉMÁSZ and E.ON) and the Hungarian national parks administration. This article includes results of the project LIFE09 NAT/HU/000384 supported by the European Commission under LIFE Nature program.

\section{Introduction}

The conversion of medium-voltage power line pylons to bird-safe and the installation of nest boxes in the pylons of high-voltage electricity lines started with the saker conservation programme.

It is known that birds have been killed along the power lines since they were first erected.

It became evident that electrocution was responsible for most deaths of certain bird species at the end of the 1970s (Bagyura 1999). The medium-voltage transmission lines are the most hazardous for birds. The most endangered species were the white stork (Ciconia cico- nia), eastern imperial eagle (Aquila heliaca), saker falcon (Falco cherrug), red-footed falcon (Falco vespertinus), common kestrel (Falco tinnunculus), European roller (Coracius garrulus), and eagle owl (Bubo bubo), but large numbers of other species were killed too, seriously endangering the survival of those species. The Monitoring Centre and the Raptor Protection Section of MME/BirdLife Hungary (MME hereafter) have been collecting and evaluateing the data from certain power lines and types of pylons since 2004.

The saker population disappeared from the plains in the mid $20^{\text {th }}$ century, and the species survived only in 

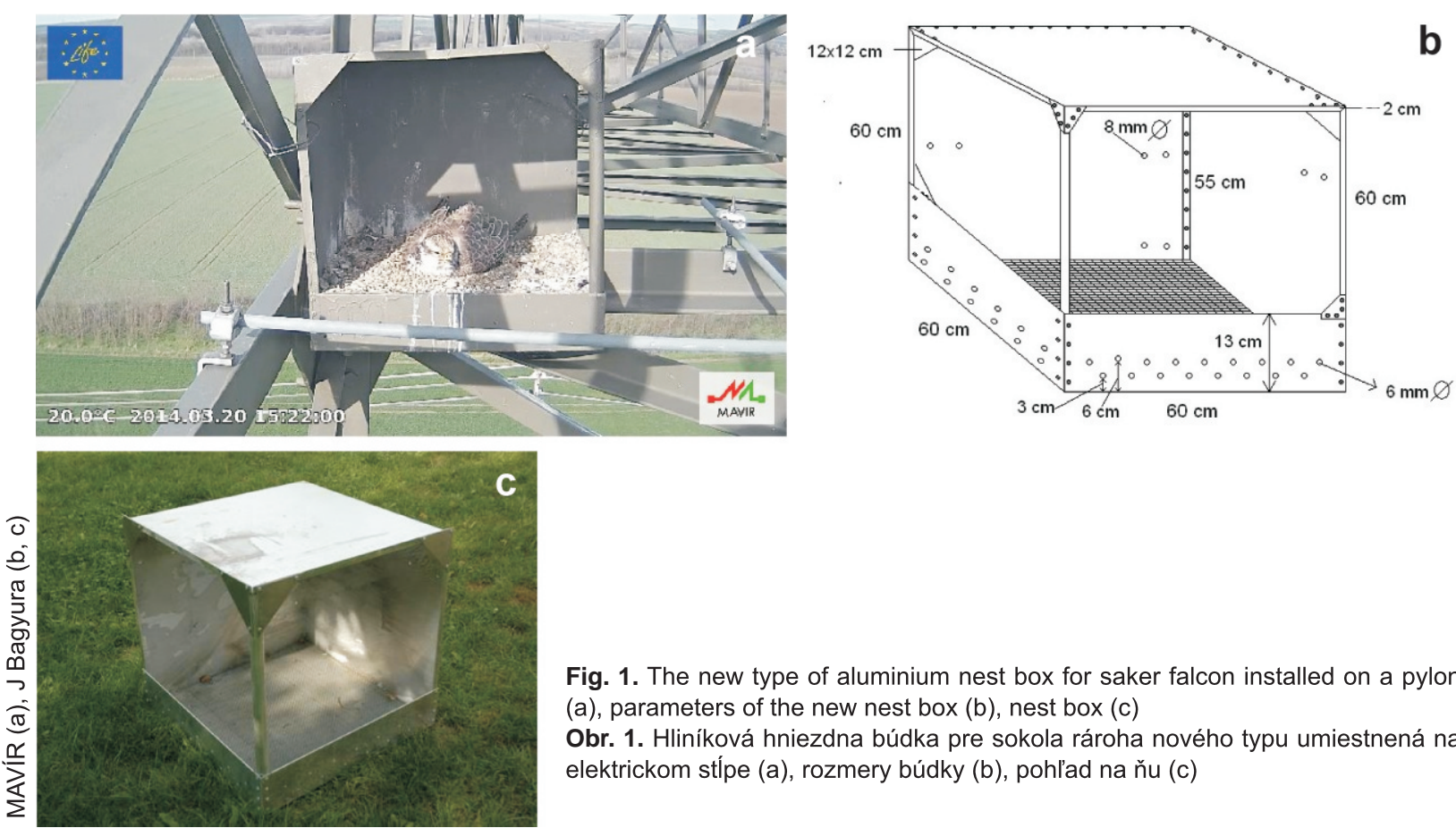

Fig. 1. The new type of aluminium nest box for saker falcon installed on a pylon (a), parameters of the new nest box (b), nest box (c)

Obr. 1. Hliníková hniezdna búdka pre sokola rároha nového typu umiestnená na elektrickom stípe (a), rozmery búdky (b), pohl'ad na ňu (c)

the mountains. There were only about $13-30$ pairs of the estimated population in 1980. There were 102 nests guarded between 1977 and 2007. Out of these 23 nestlings were unsuccessful due to various reasons, although from 79 successful breeding pairs 238 juveniles fledged. More and more juveniles settled down on the plains again, occupying ravens' and rooks' nests on the high-voltage pylons.

\section{Installation of nest boxes on the pylons of the high- voltage power lines}

The saker is historically a bird of the plains, so juveniles fledged from nests in the mountains occupied nests in agricultural areas as soon as the hunting pressure was eliminated by law. The last breeding in the mountains was observed on Gerecse mountain in 2007. Thanks to various conservation measures, more and more pairs have bred successfully in the plains. This tendency was supported by the loss of souslik-populated pastures in the foothills, where the preying possibility was reduced. Due to this tendency there is currently no known breeding saker in the mountains.

The saker is not a nest-builder, but occupies the nests of other raptor species, or ravens or rooks. Sometimes these old nests would fall down and the chicks died. To support successful breeding, in 1987 we re- placed an old nest with a new artificial one on a tree which was occupied by a saker. After that, eagle-nest size artificial nests were installed in trees which were occupied by sakers. At the beginning the artificial nests were built out of strong branches and covered with a mixture of earth and dry leaves, but these did not last long, so a more durable nest box was created and filled with gravel to ensure good water release capacity like the natural nests have. The use of nest boxes has helped the monitoring work because it is no longer necessary to search for nests annually. Together with the saker population the ravens and hooded crow populations have also increased, since they have started building their nests on high-voltage electricity pylons. The first saker breeding on a high-voltage pylon was observed in a raven's nest in 1987. The first nest box was installed on a pylon with the help of the electricity supply company in 1991.

Based on good experience with the first nest boxes, the Nature Conservation Authority and the electricity supply companies have considerably supported the programme. Thanks to the good co-operation this activity has become a nation wide programme.

In the LIFE06NAT/H/000096 project this work was speeded up between 2007 and 2010, and 301 nest boxes of a new type made of aluminium were installed on pylons (Fig. 1a). First of all the new nest boxes were used 
to replace raven and crow nests on pylons, or some old wooden or aluminium trays. This type of nest box was designed using the previous experience gained from a video monitoring breeding pairs on an aluminium tray in 2005. The new type is a covered nest box with two open sides. There are holes in the bottom of it covered with close mesh (Fig. 1b, c) and gravel. The walls of the box face the prevailing wind direction to protect the birds from strong winds. A comprehensive national survey was carried out to identify the best locations, and after that nest boxes of this new type were installed in all potential saker habitats. In 2013 nearly $70 \%$ of saker pairs nested in these new nest boxes.

\section{Conversion of medium-voltage power line pylons to bird-safe}

It is usually crossarmed concrete pylons that carry medium-voltage power lines. There are one or two standing insulators on both ends of the crossarms. The arms between the pylon and the insulators offer an ideal resting place for birds. However very often the birds cause short circuits when approaching or leaving the pylons, by touching the iron crossarms with their legs or the cable with their wings, which generally results either in death or in serious injury. Many large birds especially are killed on the plains, where there are fewer natural perching places for them. There were piles of carcases under some pylons, which was proof that the power lines in these areas have caused serious devastation of our protected birds. It has happened that after fledging we found a complete saker family killed by electric shock at two different sites. Appendix 1 includes the list of carcases that have been found during surveys co-ordinated by the MME Monitoring Centre, and Fig. 2 shows their locations. However we know from Péter Tóth's study (Tóth 2010) that the carcases we find under the pylons are just a small part of the total victims due to the scavengers. It is estimated that in reality about 100000 birds were killed annually in the past (Tóth 2010).

This problem worried not only the conservationists but the electricity suppliers as well, because the short circuits endangered the safe electricity supply for the consumers. Recognising this problem the electricity suppliers started co-operating with the state nature conservation authority and the civil nature conservationists (first of all by installing bird protecting devices on pylons). In 1987 MME contacted the electricity suppliers to work out a solution to reduce the electrocution of birds. Various possible solutions were investigated considering cost efficiency, durability and possibility of mass production at that time. Finally it was decided to develop a plastic cover for the crossarms which could prevent the possibility of short circuit, because the birds would not touch the iron bar and the wire at the same time. After that, with the help of the Magyar Villamosművek Tröszt (Hungarian Electricity Trust) MME started to design the cover, select suitable material and prepare the tools for it. It took years to get it into production and testing for suitability and durability. At the end of this process a handy "insulation slipper" was produced (Fig. 3a). The first 70 covers were installed in the Hortobágy National Park area in 1991. The bird protection work was co-ordinated by the Raptor Protection Section of MME at the beginning. Between 1991 and 2006 about 50000 pylon crossarms were covered with this kind of protector. The efficiency control survey has proved that the numbers of birds killed were reduced considerably in most cases (Fidlóczky 2010). The records of DÉDÁSZ for the Szigetvár-Barcs $20 \mathrm{kV}$ power line also show a considerable reduction $(80 \%)$ in the need for rapid re-connections after short circuits (Bagyura et al 2004). However this protective cover could not be used on all types of pylons, especially on the most dangerous ones. Between 2006 and 2014 around another 40000 pylons were made bird-safe with new types of fittings on all types of pylons.

Through two LIFE projects (LIFE06NAT/H/000096 and LIFE09NAT/HU/000384) 14300 pylons were made bird-safe in the sakers' breeding and feeding places. These make up $1 / 5^{\text {th }}$ of the most dangerous pylons. At the start of the LIFE06NAT/H/000096 project, the traditional "insulation slipper" (Fig. 3a) was used, but during the project it was replaced step by step with Ensto (Fig. 3b) and later with the Megawatt MRB-1 type devices (Fig. 3c), insulated wires (Fig. 3d) and other fittings. The electricity companies agreed to install the provided materials at their own expense. In that project mainly the pylons around the known breeding and foraging areas were covered.

In the meantime the Ministry for Environment and Water, the MME and three electricity supply companies (E.ON, ELMÜ-ÉMÁSZ, and DÉMÁSZ) signed the Unimpeded Sky Treaty on 26 February 2008. In this voluntary agreement the parties committed themselves to reducing the loss of birds through short circuit or collision with wires to the minimum possible level. They agreed on the deadline for the conversion of the 


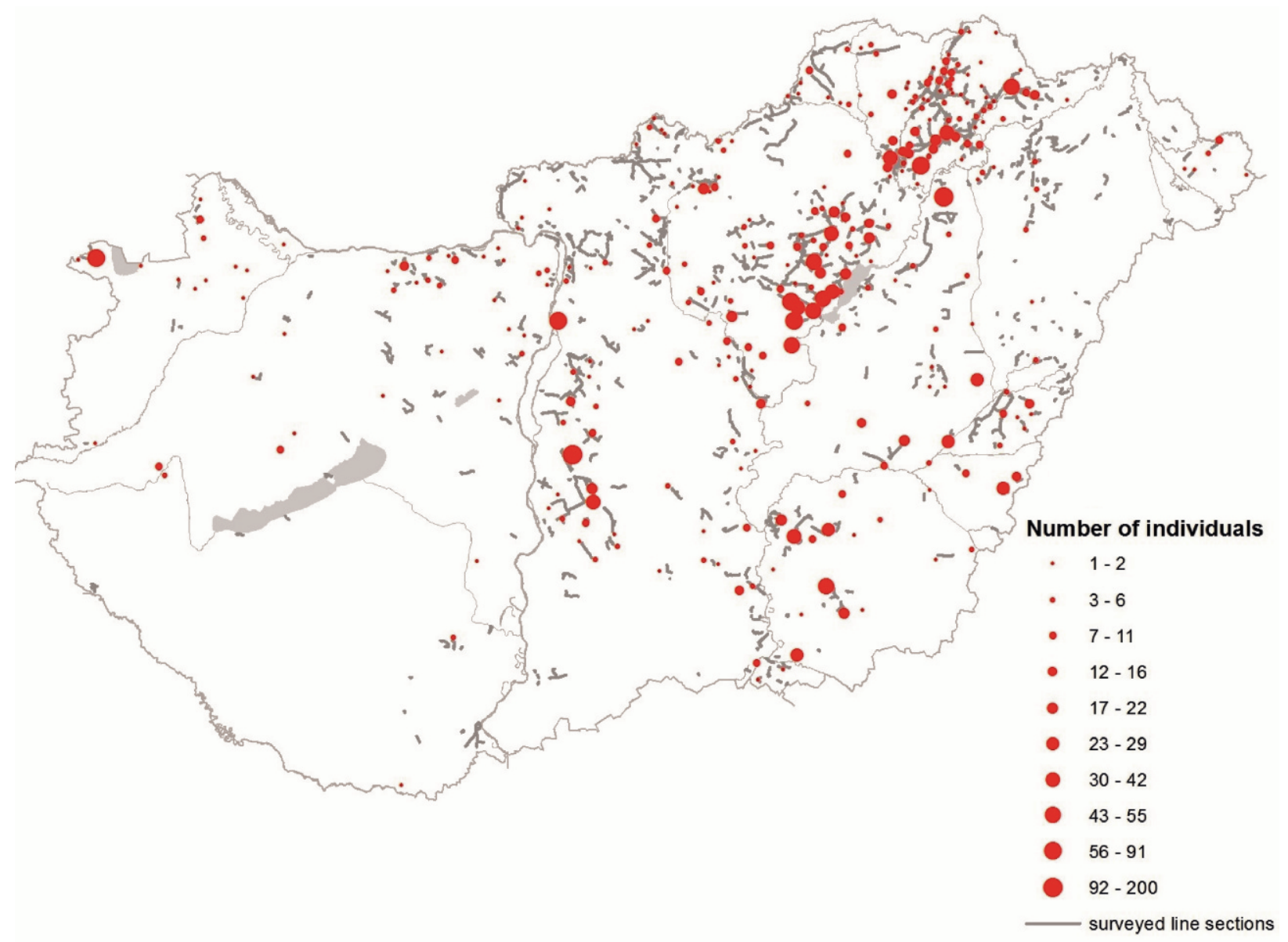

Fig. 2. Map of surveyed eletric-power line sections in Hungary (a survey of 56667 pylons covering 9 years, 2004-2013) and found birds' carcases (data source: Monitoring Centre of MME/BirdLife Hungary). For more details see Appendix 1

Obr. 2. Mapa sledovaných elektrických vedení v Mad'arsku (kontrola 56667 elektrických stípov počas 9 rokov, 2004 až 2013 ) a nájdených uhynutých vtákov (zdroj údajov: Monitorovacie centrum MME/BirdLife Hungary). Viac v Appenxixe 1

most dangerous transmission lines by 31 January 2020 .

In the LIFE09NAT/HU/000384 project two electricity companies EDF-DÉMÁSZ and ÉMÁSZ started participating as associated beneficiaries and contributing to the costs of the projects. This project has introduced a lot of new solutions.

First of all, satellite-tagged sakers' movements have been used to select the pylons for conversion. Those areas were considered first priority where satellitetagged juveniles were found roaming more frequently (Figs. 4 and 5, Appendix 1).

Secondly, a lot of new Hungarian bird protection products have become available, or some of them have been improved during the project period. The most im- portant are: new crossarmswith 3 hanging insulators ("Megawatt" type - Fig. 6a, "Eröterv" type - Fig. 6b, "Nyírmix" type - Fig. 6c) which were installed during the project, "Megawatt" MRB-2 type covering doublepin insulators (Fig. 6d), bird rests (Fig. 6e and 6f), or wing spacers (Fig. 6g). The efficiency control of the first section where Nyirmix-type crossarms were installed last year did not find any dead birds this year.

Finally, the catalogue of bird-friendly fittings for medium-voltage power lines was prepared with the active contribution of MME, which includes all birdfriendly fittings (ETV-ERÖTERV 2011).

In the meantime it has become clear that the electricity companies' staff do not know well the birds' 

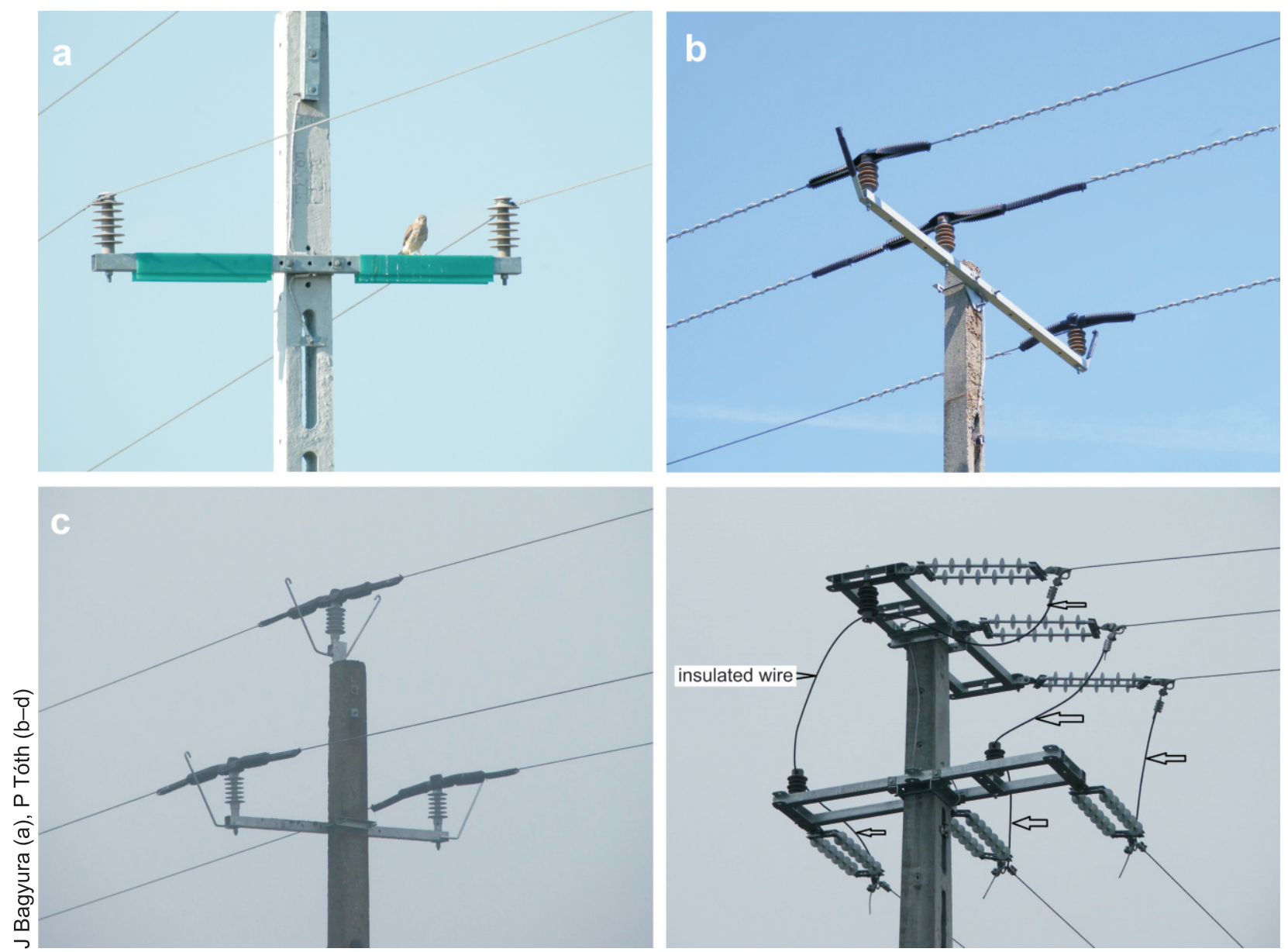

Fig. 3. This crossarmcover was the first developed bird protection device in Hungary (a), Ensto-type bird protection device (b), Megawatt-MRB-1 type bird protection device (c), insulated wires protect the birds from electrocution (d)

Obr. 3. Kryt konzoly elektrického stípa vyvinutý ako prvé zariadenie na ochranu vtáctva v Mad'arsku (a), ochranné zariadenie typu Ensto(b), ochranné zariadenie typu Megawatt-MRB-1 (c), izolované drôty chránia vtáky pred usmrtením elektrickým prúdom (d)

habits on the pylons, nor therefore the most suitable application of the existing materials. For this reason there has also been a new development that the specialists of the Bükk National Park Directorate (BNPD) subcontractor who know both the requirements for the birds' safety and the safety of the electric supply have supervised the installation work and acknowledged the completion of the work on behalf of BNPD. They have also compiled a photo catalogue of the safe pylons.

Since the installation of nest boxes on the pylons of the high-voltage power lines, many sakers have occupied these boxes. Between 2009 and 2013 out of the 809 nesting pairs 509 pairs $(73 \%)$ nested on pylons, and of those, 413 pairs occupied the new type of nest boxes
(Fig. 7).

As a result of the effort to make the medium-voltage power line pylons bird-safe:

- Between 2006 and 2010 about 7500 of the most common pylons were made bird-safe through the LIFE06NAT/H/000096 project.

- Between 2010 and 2014 about 6800 different pylons (tension, switchboard, transformer and common) of 60 power lines within 35 polygons were treated, including the installation of about 800 new crossarms with hanging insulators.

- A photographic catalogue has been prepared showing the converted pylons, which should help the electricians in case of urgent repairs to identify the needed materials for the pylon in question. 

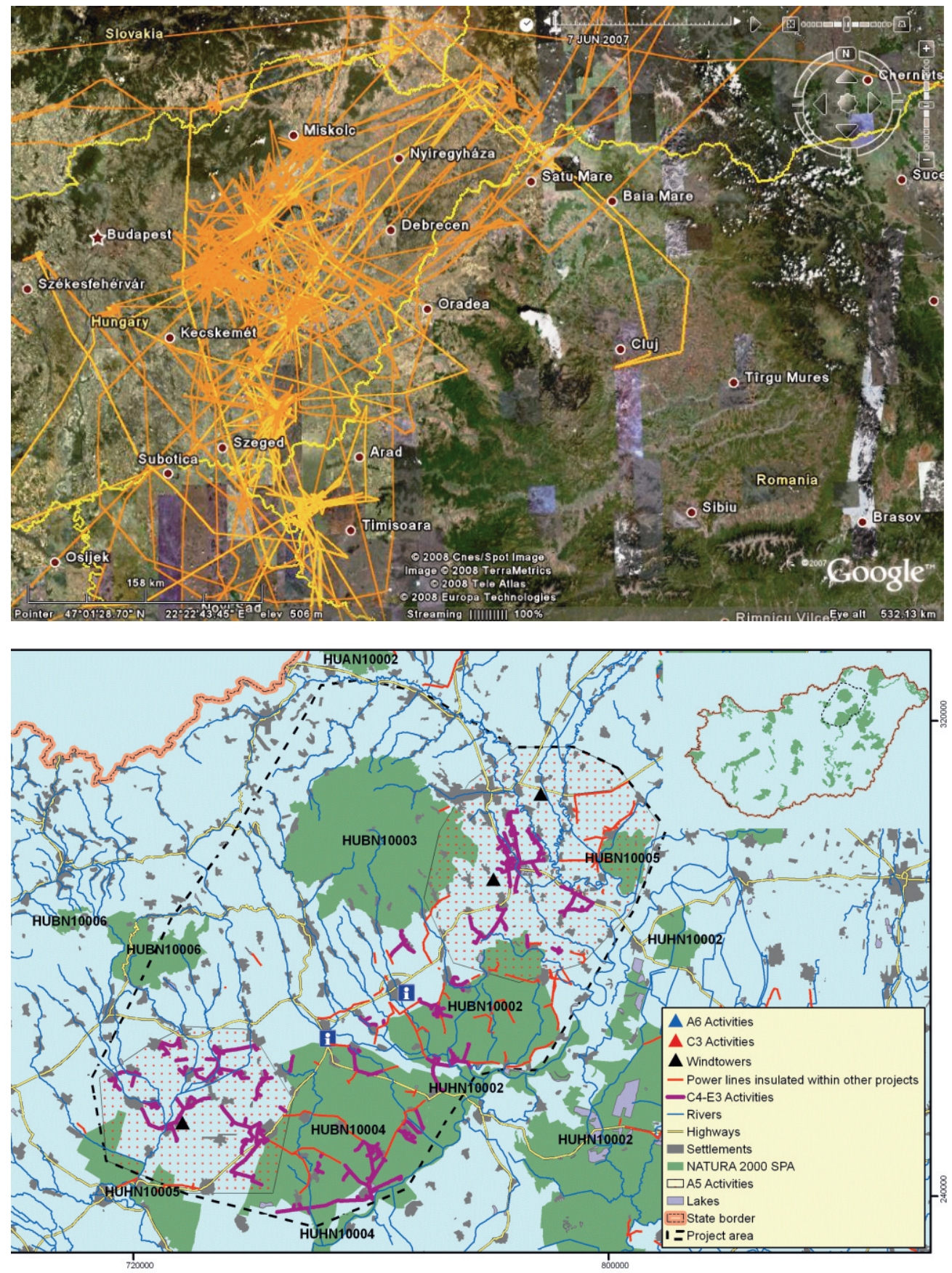

Fig. 4. Movement of satellite-tagged juveniles of saker falcon (tagged during LIFE06NAT/H/000096) was used to select the most dangerous pylons for bird protection treatment during the LIFE09NAT/HU/000384 project (base map: Google Earth)

Obr. 4. Pohyb juvenilných jedincov sokola rároha zaznamenaný pomocou satelitnej telemetrie (označených počas projektu LIFE06 NAT/H/000096) sa využil na výber najnebezpečnejších elektrických stípov, ktoré budú opatrené zariadeniami na ochranu vtáctva počas projektu LIFE09NAT/HU/000384 (podkladová mapa: Google Earth)

Fig. 5. Map of planned insulation of pylons in NE Hungary based on results of tagged juveniles' movements prepared for the LIFE09NAT/HU/000384 project proposal

Obr. 5. Mapa ochranárskych opatrení na stípoch elektrického vedenia v SV Mad'arsku plánovaných $\mathrm{v}$ projekte LIFE09NAT/HU/000384

\section{Conclusion}

The installation of nest boxes on the pylons of highvoltage power lines has been very successful. Especially the new type of nest boxes which were designed during the LIFE project has been preferred by the sakers. Today about the $3 / 4$ of the saker population breeds in these boxes (Fig. 7). The boxes provide safe sites for breeding, and make it much easier to monitor the saker population.

The most dangerous medium-voltage power line pylons have been converted to bird-safe in Hungary. In this way the mortality on power lines was reduced by at least 96\% even after the first project (Fidlóczky 2010), but the treatment and the materials have become more 
Slovak Raptor Journal 2014, 8(2): 87-95. DOI: 10.2478/srj-2014-0010.

(C) Raptor Protection of Slovakia (RPS)
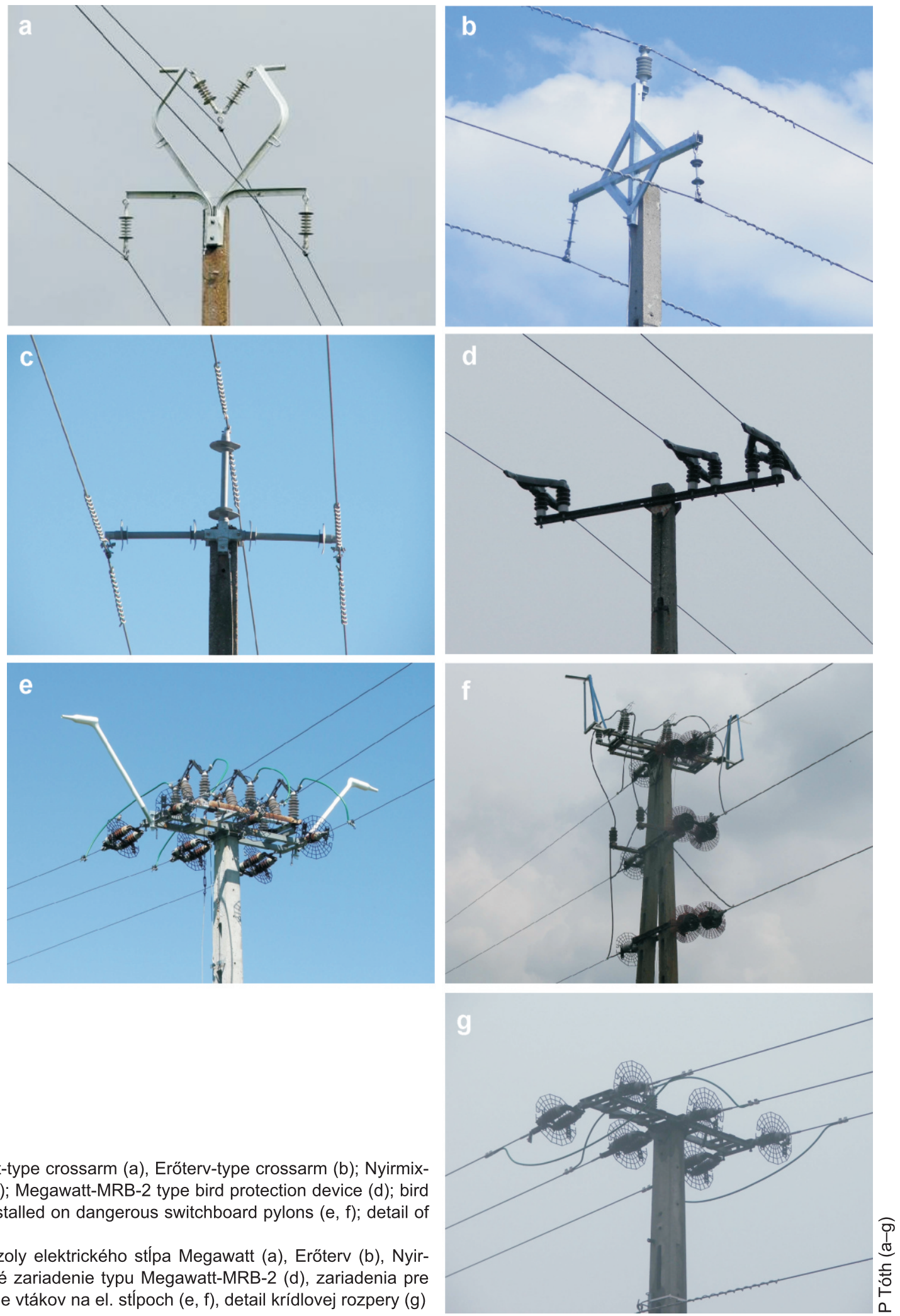

Fig. 6. Megawatt-type crossarm (a), Erőterv-type crossarm (b); Nyirmixtype crossarm (c); Megawatt-MRB-2 type bird protection device (d); bird roosting arms installed on dangerous switchboard pylons $(e, f)$; detail of wing spacers $(\mathrm{g})$

Obr. 6. Typ konzoly elektrického stípa Megawatt (a), Erőterv (b), Nyirmix (c), ochranné zariadenie typu Megawatt-MRB-2 (d), zariadenia pre bezpečné sedenie vtákov na el. stípoch $(e, f)$, detail krídlovej rozpery $(g)$ 


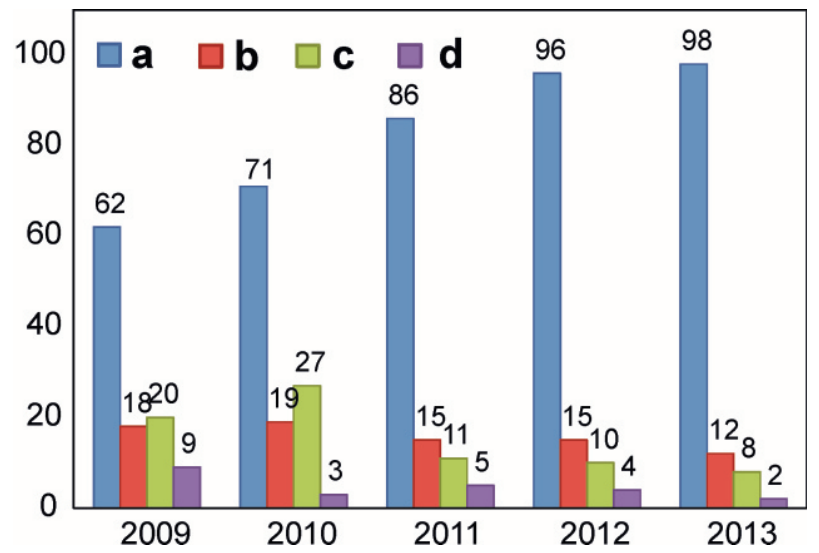

Fig. 7. Number of pairs of sakerfalcon breeding on pylons in Hungary between 2009 and 2014 according to type of a nest tray: new covered aluminium nest box (a), aluminium trays (b), wooden or plastic tray (c), natural nests (d) on pylon

Obr. 7. Počty párov sokola rároha hniezdiacich na elektrických stĺpoch v Mad'arsku v rokoch 2009 až 2014 v závislosti od typu hniezdnej podložky: nový typ zakrytej hliníkovej búdky (a), hliníková podložka (b), drevená alebo plastová podložka (c), prirodzené hniezdo (d) na elektrickom stípe

widespread and much better during the later projects, and we hope that the new crossarmswith hanging insulators will provide perfect safety.

\section{References}

Bagyura J \& Péchy T 1999: „Az áldásos áram” [“Blessing flow”]. Madártávlat 6(6): 2-3. [In Hungarian]

Bagyura J, Szitta T, Sándor I, Viszló L, Firmánszky G, Forgách B, Boldogh S \& Demeter I 2004: A review of measures taken against bird electrocutionin Hungary, 423-428. In: Chancellor RD \& MeyburgB-U (eds) Raptors worldwide. Proceedings of the VI. World Conference on Birds of Prey and Owls. World Working Group on Birds of Prey and Owls, MME/BirdLife Hungary, Budapest, 867.

Bagyura J, Szitta S, Haraszthy L, Fidlóczky J \& Prommer M 2009: Results of the saker conservation programme in Hungary, 1980-2006, 749-756. In: Sielicki J \& Mizera T (eds), Peregrin falcon populations - status and perspectives in the $21^{\text {st }}$ century.
Turul Publishing \& Life Science Press, Warsaw, 800. Bagyura J, Fidlóczky J, SzittaT, Prommer M, Tihanyi G, Zalai T, Balázs I, Váczi M, Viszló L, Klébert A, Haraszthy L, Tóth I, Török H, Demeter I, Serfőző J, Pigniczki C, Kazi R, Kováts L \& Nagy L 2011: A Kerecsensólyom-védelmi Munkacsoport 2011. évi jelentése [Annual report of the saker falcon conservation working group 2011]. Heliaca 9(1): 18-23. [In Hungarian with English summary]

Bagyura J, Szitta T, Haraszthy L, Fidlóczky J \& Prommer M 2012: Results of the saker falcon (Falco cherrug) conservation programme in Hungary between 1980-2010. Aquilla 119: 105-110.

Bagyura J \& Haraszthy L 2014: Kerecsensólyom, 573-576. In: Haraszthy L (ed.) Natura 2000 fajok és élőhelyek Magyarországon [Saker falcon. In: Natura 2000 species and habitats]. Pro Vértes Közalapítvány, Csákvár, 960. [In Hungarian]

ETV-ERÖTERV 2011: Környezetbarát 22 kV-os szabadvezeték hálózat (Madárvédelmi kialakítások a VÁT-H2 és VÁT-H20 típustervek szerint létesített hálózatokon) [Eco-friendly $22 \mathrm{kV}$ power line network (Bird protection methods on VAT-H2 and VAT-H20 type designed electric networks)]. IRÁNYTERV. Direction plan P230490. ETVERÖTERV ZRt. Budapest, 46. [In Hungarian]

Fidlóczky J 2010: Final report of LIFE09NAT/H/000096 Conservation of Falco cherrug in the Carpathian basin, 97. Retrieved October 13, 2014, from http://sakerlife.mme.hu/uploads/File/LIFE06NAT_H_000096FR 311210.pdf

Horváth M, Nagy K, Papp F, Kovács A, Demeter I, Szügyi K \& Halmos G 2008: Magyarország középfeszültségű elektromos vezetékhálózatának madárvédelmi szempontú értékelése [Evaluation of Hungary's medium voltage electric power lines from bird protection point of view]. MME/BirdLife Hungary, Budapest, 131. [In Hungarian]

Tóth P 2010: A madarakat érő áramütések nagyságrendjének becslési hibája - a dögevők hibája [Biasin the estimation of electrocution rates - scavenger removal effect]. Heliaca 8: 95-103. [In Hungarian with English summary] 
Slovak Raptor Journal 2014, 8(2): 87-95. DOI: 10.2478/srj-2014-0010.

(C) Raptor Protection of Slovakia (RPS)

\section{Appendix 1.}

List of birds killed by electrocution in Hungary based on a survey of 56667 pylons covering 9 years, 2004-2013 (data source: Monitoring Centre of MME/BirdLife Hungary)

Zoznam vtákov usmrtených na stípoch elektrického vedenia v Mad’arsku zistený počas kontroly 56667 elektrických stlpov počas deviatich rokov, 2004 až 2013 (zdroj údajov: Monitorovacie centrum MME/BirdLife Hungary)

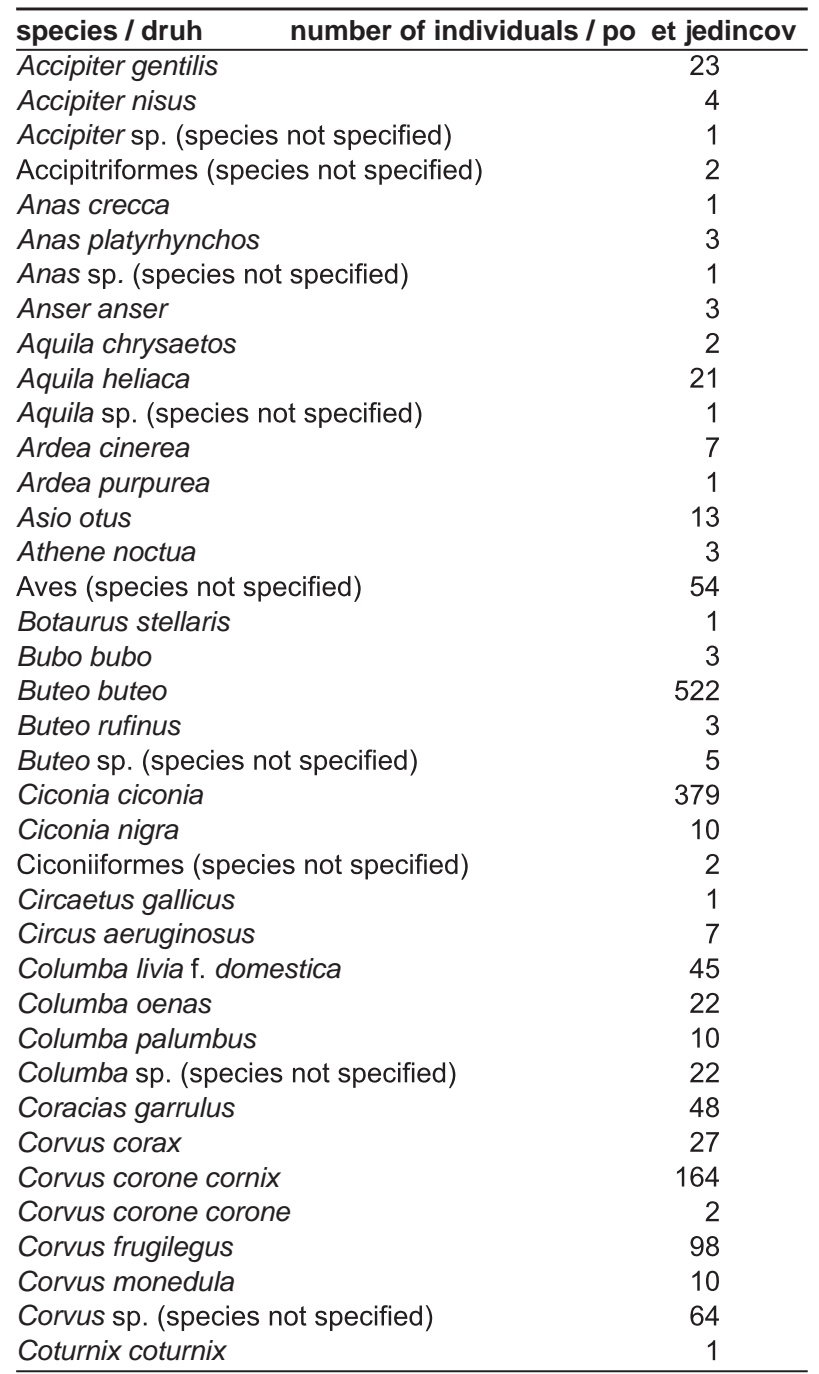

species / druh number of individuals / počet jedincov

Dendrocopos sp. (species not specified) 1

Egretta alba

Erithacus rubecula

Falco cherrug

6

Falco peregrinus

Falco sp. (species not specified)

17

Falco tinnunculus

Falco vespertinus

Garrulus glandarius

Grus grus

Haliaeetus albicilla

Lanius excubitor

Larus cachinnans

Larus canus

Nycticorax nycticorax

Pandion haliaetus

Parus major

Passer domesticus

Passer montanus

Passeriformes (species not specified)

Phasianus colchicus

6

1

Picus canus

Picus viridis $\quad 1$

Rallus aquaticus $\quad 1$

Streptopelia decaocto $\quad 45$

Streptopelia turtur $\quad 11$

Strix aluco $\quad 5$

Sturnus vulgaris $\quad 267$

Sylvia atricapilla $\quad 1$

Tringa glareola 1

Turdus merula $\quad 6$

Turdus philomelos 1

Turdus pilaris $\quad 1$

Turdus sp. (species not specified) 2

Turdus viscivorus $\quad 1$

$\begin{array}{ll}\text { Tyto alba } & 7\end{array}$

Upupa epops 1 